\title{
Peer Review and Audit Quality
}

\author{
Rita Yuniarti ${ }^{1}$, Karhi Nisjar ${ }^{2}$
}

\begin{abstract}
This study aims to examine the determinant factors of audit quality by proposing the hypothesis that peer review effect the audit quality. In this study, the unit of analysis is the external auditor who has worked in Certified Public Accountant - CPA firm. The author takes the CPA Firm in Bandung, West Java, Indonesia. Empirical test results that peer review significantly affect to audit quality in public accounting firm in Bandung.
\end{abstract}

Keyword-Audit Quality, Peer Review

\section{Introduction}

The development of the world business is increase rapidly bring many consequences for the related parties. The complexity of the transaction will further increase over this development. This change was influenced by the external business environment and government through changes in regulations or changes in the overall business climate. Corporate responsibilities for all economic events or financial transactions are summarized into a financial statements report. The financial statements have been prepared on the basis of records of transactions that have occurred in the company and created by the people the company itself [1]. To provide assurance on the reliability of the financial statements, the financial statements need to be audited, and the profession that can provide assurance over the reliability of the financial statements is a public accounting profession [2].

Arens et al., [3] said the guidance given in auditing standards and other pronouncements developed by the professional bodies help to promote audit quality by providing guidance on competencies required and the processes to be followed in achieving the required level of competence.

Rita Yuniarti

Widyatama University

Indonesia

Karhi Nisjar

Widyatama University

Indonesia
Since some of corporate failure, audit service users doubted the integrity of Certified Public Accountants, and the public confidence in the quality of audits by public accountants is decline. Public confidence in the world of the audit service profession is increasingly decline. The Public assumes that the auditor profession is a disgraceful profession because it has been duping and lying to the public [4].

\section{Peer review}

Peer review is the evaluation of work or performance by other people in the same field in order to maintain or enhance the quality of the work or performance [5].

Arens et al. [3] stated that peer review is to determine and report whether the CPA firm being reviewed has developed adequate quality control policies and procedures and follows them in practice. Reviews are conducted every three years, and are normally performed by a CPA firm selected by the firm being reviewed, although the firm can request that it be assigned a reviewer through the administering state society. Results of the peer review are included in a public file by the AICPA. Peer review benefits individual firms by helping them meet quality control standards, which in turn, benefits the profession through improved practitioner performance and higher quality audits. A firm having a peer review can further benefit if the review improves the firm's practice, thereby enhances its reputation and effectiveness, and reduces the likelihood of lawsuits. Of course, peer reviews are expensive to conduct, so the benefits come at a cost.

The quality of audit works assured by implementation of quality control measures, which firstly protect the audit process, and secondly review the result of such process. In many firms audit work is reviewed no only by person who prepared the work but also designated reviewer [6]. Rittenberg et al. [7] said that The CPA Firm should have policies and procedures in place for conducting an internal quality review of each audit before issuing the audit opinion. Reviewer was not a part of the audit team, but has appropriate competence, independence, integrity, and objectivity to perform independent review, referred to as a concurring partner.

Every 3 years, independent organizations perform a peer review of GAO's system of quality control for work done under generally accepted government auditing standards to determine whether it is suitably designed and operating effectively. The peer review 
includes a review of audit documentation, tests of functional areas, and staff interviews. The peer reviewers brief the Executive Committee, management, and staff members. The peer review of GAO's performance and financial audit practices for the year ending December 31, 2010, was completed in September 2011, providing GAO (Government Accountability Office) a clean opinion on the quality assurance system the agency uses to produce its reports and testimony to Congress " [8]. According to Garner [9] the peer review is designed to cover a one year period, with all engagement in that year becoming the pool from which the reviewer selected firm need to be reviewed self-select their reviewers and communicate arrangements to state peer review committees.

ICAI [5] said that the financial statement of companies coming out with IPO's need to be certified by firm which have been issued a certificate from the Peer Review Board. In AICPA [10] peer review consist of :

1) A system peer review.

A system peer review is an on-site review required for firms performing audits or examinations of prospective financial statements, or both.

2) An engagement peer review.

An engagement peer review is performed (offsite) when the CPA firm's highest level of service is a review of financial statements or compilation of financial statements with disclosures.

3) A report peer review.

A report peer review is performed for firms performing only compilations without disclosures.

\section{Audit Quality}

Quality is: "The Bends to the which a set of inherent characteristics fulfils requirements of an audit", and characteristics of audit quality, and audit quality is the degree to which a set of inherent characteristics of an audit fulfils requirements, audit quality is obtained by a process of identifying and aministering the activities needed to achieve the quality objectives of an SAIs [11].

Audit quality means how well an audit detects and reports material misstatements in financial statements, the detection aspect are a reflection of auditor competence, while reporting is a reflection of ethics or auditor integrity, particularly independence [3]. Riyatno [12] state that audit quality is something intangible that is difficult to measure and can only be felt by the users of audit services, thus far there is no uniform definition of the quality of the audit. According to Rittenberg [7] audit quality is assuring that the audit is conducted in high-quality manner are paramount to fulfilling users' expectations' about the auditor's role in the capital market.
Auditor must have competence in the field of audit, shown through an understanding of the standards, understanding of the audit in the electronic data processing environment, an understanding of the rules of regulatory bodies of capital markets, understanding of financial transactions, and understanding of a foreign language [13]. Sawyer's [14] stated that an increase in the quality of an audit conducted by the auditor can be measured by:

1) Generate useful findings and recommendations.

2) The achievement of the goals and objectives of the audit.

3) The increasing number of audit work requests.

The quality audit can be measured by the culture within an audit firm, the skills and personal qualities of audit partners and staff, the effectiveness of the audit process, factors outside of the control of auditors, the reliability and usefulness of audit reporting [15]. Meanwhile, according to [6] the dimensions of audit quality is:

1) Technical competence

Technical competence is defined as the auditor's ability to detect errors or shortcomings in the financial statement being checked.

2) Independence

Independence on the other hand is taken to be the willingness of the auditor to reflect in the audit report all problems and defects he/she has detected in the financial statement.

\section{Iv. Theoritical Framework}

It is important to review the audit for completeness and quality before issuing the audit report to the client [16]. Arens et al., [3] said that peer review benefits individual firms by helping them meet quality control standards, which in turn, benefits the profession through improved practitioner performance and higher quality audits.

In AICPA [10], Peer review requirements for CPA firms have changed considerably over the years. Currently, most CPA firms undergo a review of their accounting and auditing practice at least once every three years. However, the requirements vary, and not all firms have peer reviews. The audit committee should be aware of when peer reviews are required and what assurance is provided by having a peer review. Arunada [6] stated that the quality of audit works assured by implementation of quality control measures. Meanwhile, according to [17], peer review outcomes are associated with actual and perceived audit quality.

The Theoritical framework on this research is shown below :

Figure 1. Theoritical Framework

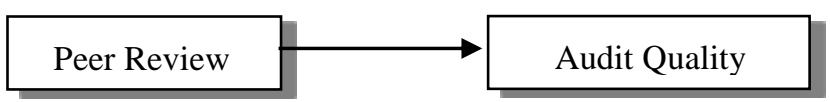




\section{v. Research Methodology}

The type of research is explanatory research, because it describes the variables and observes the correlation of these variables from the hypothesis that has been made systematically through statistical testing. The population in this study is Certified Public Accountant Firm in Bandung, West Java Indonesia. Unit of analysis in this research is the entire external auditor external auditor who has worked in Certified Public Accountant Firm in Bandung. The sampling technique use purposive method, data quality test uses the method of successive interval (MSI), validity testing, and reliability testing. Statistical test used regression.

\section{vi. Hypothesis Testing}

The hypothesis test in this study used t_test. The hypothesis is formulated as below:

$\mathrm{Ho}_{1}$ : Peer review not affect audit quality.

$\mathrm{H}_{11}$ : Peer review affect audit quality.

\section{Data Analysis}

The number of questionnaires that had spread is 56 copies from $14 \mathrm{CPA}$ firms in Bandung. The amount collected after completed by the respondents was 42 copies. After the examination, filling and full questionnaire can be used in data processing of research are 40 copies. Percentage rate that answered the questionnaire is about $75 \%$. Based on 40 respondents with $5 \%$ significance level, then $\left(\mathrm{r}_{\text {table }}\right)$ is 0.320 . On the validity test, the value of $r_{\text {calculated }}$ for all the statement items are above the value of the $r_{\text {table }}$. Its means that all the data is valid for the test. And also on the realiability test, the value of $r_{\text {calculated }}$ are greater than critical $r_{\text {table }}$, it show that all variables have good reliability, so that each item questions in all these instruments can be further analyzed.

\section{Statistic Test}

Below are the results of the statistic test after doing data processing.

TABLE 1. COEFFICIENTS (a)

\begin{tabular}{|c|c|c|c|c|c|c|c|}
\hline \multirow{2}{*}{ Model } & \multicolumn{2}{|c|}{$\begin{array}{c}\text { Unstandardized } \\
\text { Coefficients }\end{array}$} & $\begin{array}{c}\text { standardize } \\
\mathrm{d} \\
\text { Coefficient } \\
\mathrm{s}\end{array}$ & \multirow{2}{*}{$\mathrm{t}$} & \multirow{2}{*}{ Sig. } & \multicolumn{2}{|c|}{$\begin{array}{c}95 \% \text { Confidence } \\
\text { Interval for B }\end{array}$} \\
\cline { 2 - 4 } \cline { 6 - 8 } & $\mathrm{B}$ & $\begin{array}{c}\text { Std. } \\
\text { Error }\end{array}$ & Beta & & & $\begin{array}{c}\text { Lower } \\
\text { Bound }\end{array}$ & $\begin{array}{c}\text { Upper } \\
\text { Bound }\end{array}$ \\
\hline 1 (Constant) & 2.687 & 1.407 & & 1.910 & .067 & & \\
$\mathrm{X}_{-} 1$ & .560 & .192 & .216 & 2.923 & .007 & .004 & 12.233 \\
\hline
\end{tabular}

Structural equation: $\mathrm{Y}=2.687+0.560 \mathrm{X}_{1}+\varepsilon$

TABLE 2. MODEL SUMMARY (b)

\begin{tabular}{|l|c|r|r|r|c|}
\hline Model & $\mathrm{R}$ & $\begin{array}{c}\mathrm{R} \\
\text { Square }\end{array}$ & $\begin{array}{c}\text { Adjusted } \\
\text { R Square }\end{array}$ & $\begin{array}{c}\text { Std. Error of } \\
\text { the Estimate }\end{array}$ & $\begin{array}{c}\text { Durbin- } \\
\text { Watson }\end{array}$ \\
\hline 1 & $.966(\mathrm{a})$ & .934 & .904 & 1.21500 & 1.722 \\
\hline
\end{tabular}

Based on the table, can be concluded that peer review affect audit quality as much as $93.40 \%$, and $6.6 \%$ is influenced by factors beyond peer review. Hypothesis testing result show that peer review significantly affect to audit quality.

\section{Ix. Conclusion}

Peer review affect to audit quality. To improve audit quality, Certified Public Accountant Firm in Bandung should review of audit documentations in one year period and tests of functional area in one year period.

\section{Acknowledgment}

We thank Prof. Azhar Susanto for assistance with particular technique, methodology, and for comments that greatly improved the manuscript, and Widyatama University for financial support.

\section{References}

[1] Rita, Yuniarti. 2011. Audit Firm Size, Audit Fee and Audit Quality.Journal Of Global Management. Vol 2 Issue 1

[2] Agoes, Sukrisno. 2008. Auditing: Pemeriksaan Akuntan oleh Kantor Akuntan Publik. Jilid I. Edisi Kedua. Lembaga Penerbit: Fakultas Ekonomi Universitas Indonesia.

[3] Arens, Alvin A. Elder, Randal J. Beasley, Mark S. 2012. Auditing and Assurance Services an Integrated approach, $14^{\text {th }}$ edition. Pearson Prentice Hall.

[4] Iman P. Hidayat. 2007. Impact of Financial Numbers Game. http://imanph.wordpress.com/2007/12/12/dampak -financial-number-game/.

[5] ICAI (The Institute Of Chartered Accountants India). 2002. Peer Review Board.

[6] Arrunada, Benito. 1999. The Economics of Audit Quality: Private Incentives and The Regulation of Audit and Non-Audit Service.

[7] Rittenberg, Larry E., Johnstone, Karla. M., Gramling, Audrey. A. 2010. Auditing A Business 
Approach. $7^{\text {th }}$ edition. South-Western Cengage Learning.

[8] Government Accountability Office. 2011. International Peer Review of the Performance and Financial Audit Practices of The United States.

[9] Garner, Don E. 2008. Accounting and The Global Economy After Sarbanes-Oxley.

[10] AICPA (American Institute of CPAs). 2010. Peer Review of CPA Firms: An Overview.

[11] Guidelines on Audit Quality.Version 29 October 2004 Revised version for the consideration of Contact Committee of the Heads of the SAIs of the European Union, Luxembourg, $6-7$ December 2004.

[12] Riyatno.2007.Pengaruh Ukuran Kantor Akuntan Publik Terhadap Earnings Response Coefficients.Jurnal Keuangan dan Bisnis,Vol. 5, No.2, Oktober 2007.

[13] Islahuddin. Soesi. 2002. Persepsi Terhadap Kualitas Akuntan Menghadapi Tuntutan Profesionalismen di Era Globalisasi. Jurnal Manajemen dan Bisnis Vol.4 2002.

[14] Sawyers, Lawrence B. 2006. Internal Auditing. Jakarta :Salemba Empat.

[15] Johnstone, Karla M., Rittenberg, Larry E., Gramling, Audrey. A. 2012. Auditing A Business Approach. $8^{\text {th }}$ edition.South-Western Cengage Learning.

[16] Johnstone, Karla M., Rittenberg, Larry E., Schwieger, Bradley J. 2008. Auditing A Business Risk Approach. $6^{\text {th }}$ edition. Thomson South Western.

[17] Hilary, G., and Lennox, C. 2005. The credibility of self-regulation: Evidence from the accounting profession's peer review program. Journal of Accounting and Economics.

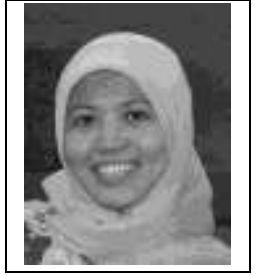

Rita Yuniarti is currently affiliating with Widyatama University as a lecturer. Research interests include auditing, and management accounting

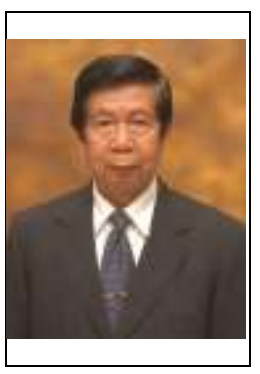

Karhi Nisjar is currently affiliating with Widyatama University as a lecturer. Research interests include public accounting, and auditing 